\title{
Análisis iconográfico de las portadas de las ediciones escolares del Quijote entre la II República y el Franquismo
}

\author{
Luis Rodrigo MARTín* \\ Aurora LóPEz LÓPEZ**
}

\begin{abstract}
Resumen
El Quijote es la obra más reconocida de la Literatura en España y de la Literatura Universal, de ahí la importancia de llevar su lectura y conocimiento al espacio escolar a través de adaptaciones pedagógicas para su comprensión por el público infantil. La obligatoriedad de su lectura durante el período comprendido entre la II República y el Franquismo provocó numerosas ediciones escolares que tenían por objeto satisfacer su enseñanza en las aulas. Este estudio, centrado en la paratextualidad de la obra desde una perspectiva comunicativa e iconográfica, permite a través del análisis de contenido de las portadas de una muestra catalogada y representativa de adaptaciones escolares, comprobar que el duro intervencionismo político que sufrió la obra según ideologías dominantes antagónicas no influyó sobre su diseño, en tanto no sirvió a la connotación ideológica de estos espacios, a pesar de ser el primer elemento de persuasión comercial del libro y su función la de motivar a la lectura. Así, los datos de tipo analítico junto con los históricos explican la existencia de una imagen comercial del Quijote escolar despolitizada (la de la portada), reflejo de su trayectoria iconográfica, en la que no se han encontrado diferencias sustanciales atribuibles a las distintas doctrinas políticas. Sin embargo, el énfasis político sobre la obra erigió al Quijote en el héroe nacional de niños y adultos, convirtiéndolo en un referente universal de comportamiento, elogiable por sus grandes valores éticos y morales.
\end{abstract}

Palabras Clave: Quijote; Iconografía; Comunicación; Adaptaciones escolares; Intervencionismo político; Universalización. 
Title: Iconographic analysis of the covers of school editions of Don Quijote between the Second Republic and Francoism.

\begin{abstract}
Don Quixote is the most recognized work of Spanish and universal literature, and teaching adaptations in schools are very important for children to understand their reading. Compulsory reading of the work during the period between the Second Republic and the Franco regime caused many school adaptations to suit their classroom teaching. This study focused on the graphic elements of the work from a communicative and iconographic perspective, allows through content analysis of a cataloged and representative sample of the covers of school adaptations, verify that the hard political interventionism that suffered the work according antagonistic dominant ideologies did not influence their design, because these spaces were not ideologically charged, despite being the first element of commercial persuasion of the book and its role motivate reading. Analytical data along with historical explain the existence of a commercial image of Quixote free of ideological connotations (on the cover), from his iconographic path, which we have not found significant differences from the two dominant ideologies. However, the politicization of the work contributed to Don Quixote became the national hero of children and adults and a universal benchmark of behavior full of great ethical and moral values.
\end{abstract}

Key Words: Quixote; Iconography; Communication; School adaptations; Political interventionism; Universalization.

\title{
INTRODUCCIÓN
}

El libro escolar supone todo un símbolo en el fomento de la lectura para nuestro sistema educativo, pero no proporciona en exclusividad cultura escrita sino también cultura iconográfica e iconológica, y «la recepción del mensaje ilustrado precisa de un proceso de aprendizaje, mediante el cual se adquieren competencias básicas para la lectura y sociabilización del niño» (Durán, 2005: 239). Toda una afirmación que nos lleva a pensar en la capacidad tanto comunicativa como persuasiva de las imágenes.

En este sentido, el Quijote, como obra excelsa de la literatura española $\mathrm{y}$, por ende, tradicionalmente adaptada para su lectura en el ámbito escolar, presenta una riqueza inigualable en cuanto a su análisis dicotómico en tanto que signo/documento (Eco, 1977), ya que no solo trasciende globalmente como icono cultural en nuestra sociedad, sino que, en un plano más académico y científico, ha generado desde siempre y genera toda una variedad de estudios, que Barton y Hamilton (1998) explican bajo la policontextualidad que los aglutina.

En este sentido nuestra contribución, partiendo de entender la transtextualidad de la obra y, de este modo, su adaptación a diferentes discursos, se instalaría, en el sentido más puramente literario, en el campo de la paratextualidad (Genette, 1989), tomando el peritexto como objeto de estudio, ya que 
ahonda en la parte visual de la obra, y que en gran medida define el criterio editorial al abarcar aspectos múltiples:

[...] como el nombre del autor, un título, un prefacio, ilustraciones, que no sabemos si debemos considerarlas o no pertenecientes al texto, pero que en todo caso lo rodean y lo prolongan precisamente por presentarlo, en el sentido habitual de la palabra, pero también en su sentido más fuerte: por darle presencia, por asegurar su existencia en el mundo, su «recepción» y su consumación, bajo la forma (al menos en nuestro tiempo) de un libro. [...]. El paratexto es para nosotros, pues, aquello por lo cual un texto se hace libro y se propone como tal a sus lectores, y, más generalmente, al público. Más que de un límite o de una frontera cerrada, se trata aquí de un umbral, $[\ldots]$, de un «vestíbulo» que ofrece a quien sea la posibilidad de entrar o retroceder. (Genette, 2001: 7).

Pero además, y si efectivamente leer a Cervantes desde el cervantismo no nos permitirá ver nada más allá del cervantismo (Arlandis, 2009), una vez comprendida su obra como hecho histórico-literario conectado a diversas manifestaciones artísticas, que han convertido a autor y obra en emblemas culturales, estéticos e ideológicos atemporales, cabe admitir también la legitimidad de aproximarnos a su estudio en base a una metodología multidisciplinar que comprenda simultáneamente el análisis comunicativo, iconográfico e iconológico de la obra, teniendo en consideración ese su principal carácter universal. Para ello, esta investigación se centra en el análisis en exclusiva de las portadas de una amplia muestra de ediciones escolares del Quijote fechadas entre la II República y el franquismo.

En este sentido, buscamos aportar una visión distinta desde el ámbito de la comunicación, que ofrezca nuevos datos acerca de la instrumentalización (Guereña, 2008) del Quijote en el espacio escolar como icono nacional para el periodo histórico comprendido. Cuestión que no podrá satisfacerse adecuadamente sin atender a la historia de nuestro país, y más en concreto aún, a la historia de la educación, y como ésta a su vez ha sido entendida por los españoles y sus gobiernos en función de los diferentes períodos considerados, entre otras aportaciones científicas de gran valor.

\section{ESTADO DE LA CUESTIÓN EN TORNO AL ESTUDIO DEL QUIJOTE ESCOLAR}

Para la realización de este trabajo es fundamental realizar una primera revisión, aunque apenas quede reducida a mención simple, tanto de los catálogos de las ediciones del Quijote como de algunas de las contribuciones bibliográficas más importantes que ha suscitado la obra, a fin de poder contextualizar el sentido de esta investigación, dado que se apoya sobre una muestra previamente catalogada, y que por sus orígenes mantiene una vinculación directa con numerosas aportaciones científicas de interés, que nutren este estudio de la adaptación escolar de la obra cervantina según el enfoque adoptado. 
De acuerdo a Lucía (2006), todavía tenemos que recurrir a la utilización de los catálogos bibliográficos de finales del siglo XIX y principios del XX, entre los que destaca los de Rius (1895-1905) y Suñé (1605-1917), cuyas consultas pueden ampliarse o complementarse con otras búsquedas en internet pero cuyas fuentes no son siempre fiables. A su vez, junto a los catálogos más rigurosos respecto de las exposiciones de tipo cervantino y quijotesco, como son los de la Biblioteca Nacional de España, las exposiciones cervantinas han servido también para recuperar o sacar a la luz fondos bibliográficos poco conocidos, como los de la Biblioteca Nacional de Cataluña, o el de REBIUN de las bibliotecas universitarias españolas, y entre los que destacan los elaborados por: Lucía (2005); Porro (2005); Torres (2005); Montaner (2005); Diputación de Málaga (2005); Sanz (2005); Contreras, Fernández y Armenteros (2005). Además, de otros interesantes catálogos de bibliotecas como el Catálogo de la Biblioteca Cervantina de la Fundación Ramón Álvarez Viña; Quixot IV centenari (1605-1905): Edicions del Quixot a la Biblioteca Pública Episcopal del Seminari de Barcelona; En torno al Quijote. Adaptaciones, imitaciones, imágenes y música en la Biblioteca; Aventuras del Quijote en la UNLP. Sin olvidar, sin embargo, que se considera una de las aportaciones más valiosas el Catálogo de la colección cervantina de la Biblioteca Nacional. Ediciones del «Quijote» en castellano ${ }^{1}$. En otro contexto aledaño, es más que razonable recordar la labor editorial de la Academia del Hispanismo (Arlandis, 2009), dada la relevancia de su contribución a la difusión y compresión de la obra del famoso hidalgo Don Quijote de la Mancha.

Igualmente, de entre la innumerable recopilación bibliográfica que permite consultar la obra cervantina para conocerla mejor, representan una parte muy importante las adaptaciones escolares, por cuanto contribuyeron a identificar la obra cervantina con la patria española desde edades tempranas, al utilizarse como recurso político de manera intencionada y prolongada en nuestro país con independencia de la ideología dominante (Guereña, 2008). La importancia de esto conecta a su vez con las numerosas exposiciones que han tenido lugar en los últimos años en torno al Quijote escolar, tal y como sucede con la muestra objeto de nuestro análisis ${ }^{2}$.

En este contexto, es más que razonable situarse ante el origen y sentido de la obra escolar. El período ilustrado, especialmente a partir de la segunda mitad del Siglo XVIII, es característicamente representativo del creciente interés que la Educación adoptaría en tanto que ámbito de inspiración totalmente propicio para la producción, edición y comercialización de obras escolares. Fue notoria entonces, la labor editora del movimiento reformista de San Ildefonso ${ }^{3}$, por cuanto supuso grandes avances en la adaptación de las cartillas y otras obras escolares a las di-

1. Se puede consultar toda esta información más detallada en la fuente original: Lucía Megías (2006): 271-277.

2. Sotomayor y Navarrete (2005).

3. Para más información sobre este tema véase Sureda García (1997: 69-100). 
rectrices e innovaciones pedagógicas del momento. Pero debido a que es en esta época cuando aumentan los niveles de escolarización de la sociedad española, a la par que surgen nuevas instituciones educativas, que los docentes, dado su precario salario, comienzan a ver en el sector del libro la oportunidad de obtener nuevos ingresos complementarios; una fórmula que tiene una especial raigambre, a su vez, en el hecho de que a lo largo de la historia su figura haya sido utilizada por diferentes gobiernos para el desempeño de las tareas vinculadas a la selección y autorización de los libros de la etapa escolar primaria y secundaria, y de lo cual también los profesores sacarían su provecho. Tanto es así, que tras la instauración del régimen liberal a la muerte de Fernando VII, se asientan las bases de la política sobre libros de texto que marcará la etapa contemporánea, y en cuya trayectoria se aprecia de un lado esa influencia visible de los docentes sobre la difusión y venta de obras escolares de forma tan pródiga que muchos se convierten en editores $\mathrm{Su}-$ reda, 1997), mientras destaca por otra parte la labor de ciertas empresas editoriales, que entablaron novedosas técnicas promocionales y que terminaron en el siglo XX ejerciendo el control sobre el anterior sistema de autores-editores. De entre ellas, han sido estudiadas y merecen especial mención, algunas de las que más trascendieron a estos efectos, como: Dalmau, Calleja, Hijos de Santiago Rodríguez, etc.

De entre los libros escolares sometidos a esta lucha constante entre reformas políticas, comerciales y hasta morales, el libro de lectura ha sido por antonomasia el que mayor negocio ha causado. Por su importancia económica también, dada su capacidad de venta superior, y su mayor presencia en las escuelas con respecto de otros de tipo más específico y relativos a materias como la geografía o las ciencias naturales, por poner un ejemplo, se explica el hecho de que el mismo haya sido visto siempre como un suculento elemento de adoctrinamiento político y religioso, siendo objeto por tanto de continuos controles. Una circunstancia poco de extrañar ante un panorama como el descrito, que ha ido dejando una herencia imborrable en el transcurso del tiempo y de la historia, que ha servido también para explicar grandes problemas del ámbito educativo que perduran todavía en la actualidad fruto de ese bagaje ${ }^{4}$.

Interesa recordar, continuando con el análisis de la obra escolar, que a principios del XX de los cuatro componentes del libro: el textual, el tipográfico, el iconográfico y el material, de acuerdo con Petrus (1997), es el aspecto iconográfico el que más novedades significativas presenta, ya que de cara al progreso visible pasado el primer tercio de siglo, se avanzará de manera muy positiva en la utilización de procedimientos de impresión más modernos como fueron la litografía ${ }^{5}$ y su variedad el offset, y el huecograbado. Así, es necesario recordar desde la historia de la ilustración la impronta del género de la ilustración infantil (García, 2004) en tanto actividad que ha marcado

4. Es interesante, de acuerdo con esta afirmación, la lectura del documento publicado por Ortiz de Orruño (1998: 15-23).

5. Para mayor información sobre la mejora que conllevó esta nueva técnica de impresión véase Boix (1925). 
desde siempre el sentido de las obras pedagógicas. Y además, porque en líneas generales, el importante legado iconográfico vinculado a la obra cervantina ha sido objeto de estudio de muy diferentes obras, como: Urbina y Maestro (2005); Giménez, Andrés y Rius (2005); Alvar et al. (2004); Riley (1988), por destacar algunas de las interesantes para este estudio.

Pero no sólo esto atañe a la delimitación de nuestro objeto de estudio, en el cual compete también articular ciertos matices históricos que tratarán más de cerca algunas de las concomitancias que cumplimentarán las respuestas ofrecidas tanto en el transcurso como al final de esta investigación. Tiene que ver con ello, el tema de la politización de la educación en nuestro país, y que a pinceladas en materia de libros escolares servirá para ilustrar en líneas generales esta tendencia para las épocas relativas a los dos regímenes políticos protagonistas del periodo estudiado.

Así, de una parte atendiendo a Puelles (1997), la segunda República puede dividirse en tres períodos políticos muy diferenciados: el bienio azañista, el bienio radical-cedista y la guerra civil. En materia de política escolar, conviene comenzar destacando que durante la II República se vuelve al sistema de listas de libros autorizados, que quedó revocado tras la Dictadura de Primo de Rivera por otro de libro único editado por el Estado, que desde La Restauración hasta ese momento ya había funcionado. Para que tales obras respondieran a la simbología, lenguaje y valores republicanos, se concedió la función de velar por ello al Consejo de Instrucción Pública que creó el gobierno provisional. A estos efectos se estableció la orden ministerial de 28 de Mayo de 1932. En esta se instaba a valorar el rigor pedagógico y científico de las obras, pero también a considerar su coste económico, para la selección de los libros, al igual que a contemplar que las ideas de los textos estuvieran en consonancia con las de la República. Para ofrecer a editores y autores la oportunidad de conocer el nivel de aceptación que tendrían sus obras, se convocó un concurso para someterlas a examen por orden de 21 de Junio de $1932^{6}$, cuyas aprobaciones surtieron la lista de libros autorizados que se publicó en 1934, y que según Tiana (1997), dio fe de que se trató de los criterios más restrictivos nunca anteriormente aplicados en este sentido, debido a la corta lista de los que fueron aceptados ${ }^{7}$

De entre los libros de texto de la escuela a lo largo de este período destacan las fábulas y las biografías de autores ilustres y personajes importantes, no obstante pierden gran protagonismo las obras más clásicas, así como muchos autores ven frenada su producción o muy reducida, como les sucedió a Esteban Paluzíe o Pilar Pascual de Sanjuán, Dalmau Carles, Saturnino Calleja y Eugenio García Barbarín, mientras otros nuevos comienzan a verse frecuentemente citados: Solana, Muro, Pla, Palau o Escofet ${ }^{8}$.

6. La lectura obligatoria por trozos de la obra cervantina se establece mediante un real decreto de 6 de marzo de 1920 .

7. Para más información sobre este tema véase: Tiana Ferrer (1997).

8. Escolano Benito (1997). 
En cuanto a la política del libro escolar en el franquismo, atenderemos a la división histórica propuesta igualmente por Puelles (1998), dado que de igual modo guarda relación con las políticas de educación del régimen franquista diferenciando tres etapas de análisis: 1) El franquismo de orientación totalitaria (1939-1945); 2) El franquismo nacionalcatólico (1945-1957); 3) El franquismo tecnócrata (1957-1975).

En la primera fase del franquismo se instauran los valores primordiales que se mantendrían a lo largo de todo el régimen casi de forma inalterable y que responden a un ejercicio permanente del caudillismo centrado en la falta de libertades, totalitario y perseguidor de cualquier ideología contraria, como el socialismo y el comunismo, por destacar los principales pensamientos políticos más rechazados por el régimen y que más militancias activas opositoras representaron. Prueba de ello, en relación a la política escolar, es la orden de 4 de septiembre de 1936, que exigía en todas las escuelas y bibliotecas la incautación y destrucción de todos los libros que tuvieran matices socialistas y comunistas, y se asegurase la visibilidad exclusiva de aquellos que respetaran las máximas de la religión y moral cristianas.

Sin embargo, durante este período, esto sería solo el primer intento de intervención de la educación por parte del régimen pero no el último en garantizarse el fervor a su ideología, pues seguidamente saldrían a la luz otras leyes con el ánimo de controlar la escuela: la orden de la presidencia de la Junta Técnica del Estado, de 21 de septiembre de 1937, para la elaboración del «Libro de España», como libro único de lectura para todas las escuelas de España; la orden de 11 de abril de 1938, que supone un paso más restrictivo y de mayor control, encargando al Instituto de España la elaboración de los libros de materias que serían obligatorios en la enseñanza primaria; la órdenes del 20 de agosto de 1938 y de 20 de Octubre de 1939, creadas para vigilar las ventas de la industria escolar española, que revocaron el excesivo control anterior permitiendo la venta de otros libros pero bajo el sistema de autorización y censura previa, establecido como es sabido para ejercer principalmente el control político; hasta llegar a las órdenes de 8 de Mayo de 1941 y 17 de julio de 1945, como claves para el cierre de este período, referidas a la unificación de criterios y procedimientos legales que serían tenidos en cuenta para la aprobación de los libros escolares cuidadosamente fijados para conseguir el adoctrinamiento ideológico nacional y católico.

En la segunda fase:

[...] la derrota militar de los fascismos europeos aceleró la adaptación del franquismo a la nueva situación. Términos como fascismo, totalitarismo, raza, sangre, imperio, etc., van a ser expulsados del lenguaje oficial y sustituidos por otros que, presentes en mayor o menor grado, pasan ahora a primer término: catolicismo, movimiento, reino, subsidiariedad...Es el tránsito a la democracia orgánica, [...] que después se llamó el nacionalcatolicismo. (Puelles, 1998: 56-57). 
Una coyuntura marcada por el cambio político-educativo liderado por Joaquín Ruiz Giménez desde 1951, y en la que cabe destacar en 1953 la creación del bachillerato elemental y la aparición de los primeros Cuestionarios de las escuelas primarias como voluntad inicial clara del régimen para considerar una renovación pedagógica. En esta línea se intentaba conciliar la libertad del profesor como generador de textos educativos sin olvidar el cumplimiento de ciertas condiciones que velaran por mantener la estabilidad ideológica y religiosa conseguida en la etapa inmediatamente anterior. Muestra de la defensa simultánea de estos intereses son las comisiones creadas en el ministerio para la valoración de los libros de texto, de entre las cuales una de ellas se dedicaba en exclusiva a los manuales escolares velando por la inclusión de los elementos de adoctrinamiento didáctico, mientras que otra comisión se encargaba de dictaminar o asesorar acerca del precio ideal para su venta al público 9 .

Sin embargo, por cuanto incumbe a este estudio, es importante señalar que lo más significativo de este periodo tiene que ver con la aprobación del decreto de 22 de septiembre de 1955 que incorporaba novedades para la selección de los libros de texto de primaria a partir de ese momento, especificando de manera completamente minuciosa las características generales que debían reunir dichos libros (tamaño, cubierta, encuadernación, tipografía, ilustraciones...), y además describiendo igualmente aquellas otras características especiales que debían reunir los libros de iniciación a la lectura, los de lectura propiamente dicha y los destinados a las bibliotecas escolares (carácter cíclico, adaptación a la edad, métodos de iniciación, vocabulario, etc.), y en última instancia, y de entre los que pasaran esa selección se llevaba una definitiva clasificación acorde a: libros de mérito, libros aprobados, libros no autorizados y libros premiados (Puelles, 1998) ${ }^{10}$.

En cuanto a la fase tecnócrata del régimen, caracterizada por la salida del período autárquico mediante una modernización que supuso un notable desarrollo económico para el país, se van a procurar avances educativos significativos de distinta índole que sin desviarse del objetivo prioritario del régimen por mantener su poder y autoritarismo político, van a suscitar cambios propios de la debilidad ideológica que también define este período de forma considerable en sus últimos diez años (1965-1975). En este punto clave cabe mencionar la reforma educativa emprendida por Villar Palasí de 25 de Marzo de 1965 que enérgicamente invitaba a considerar la introducción de cambios importantes para la mejora de los libros de texto de la enseñanza media que permitieran conseguir mejores contenidos científicos, una mayor calidad pedagógica y también mayores niveles de calidad material, así como aumentar la libertad

9. El precio de venta al público de los libros es un tema que merece especial análisis. Para ilustrar de algún modo su evolución, sirva el ejemplo de Beas y Montes (1998: 77), en el que como indican, mientras un libro de texto costaba en el año 1967 alrededor de las 50 pesetas, para 1976 ya costaba 249 pesetas.

10. Otra referencia para ampliar esta información es: Sánchez-Redondo Morcillo (2004). 
metodológica de los autores a favor de una convivencia de los planos político y religioso regionales y nacionales con los internacionales.

$\mathrm{Y}$ aunque ni con esta reforma, ni con otras legislaciones inmediatamente posteriores, como la aprobación de la ley general de Educación de 1970, se consiguió derrocar la labor censuradora ideológica del régimen en torno a los métodos y libros de enseñanza, como se hubiera pensado con la creación además del Instituto de Ciencias de la Educación para la supresión de los tradicionales comisiones a dichos efectos que determinaba la orden de 27 de febrero de 1971, sí que al final de esta etapa, mediante el decreto de 20 de julio de 1974 se produce un primer salto cualitativo en cuanto a cómo eran los procedimientos anteriores en esta materia, que reconocía por vez primera que la elección de los libros estuviera sujeta a la labor de los claustros de los centros de educación general básica y formación profesional, así como a los seminarios didácticos en los centros de bachillerato. Además, por primera vez también, dicha selección debía realizarse en común con la asociación de padres de alumnos del centro. Por todo ello, este decreto se consideró un hecho muy revelador de lo que se denominó tardofranquismo o pretransición ${ }^{11}$.

\section{METODOLOGÍA}

Como se ha puesto de manifiesto en el estado de la cuestión, el interés que desde siempre ha despertado el Quijote, y las circunstancias históricas que han acompañado sus continuas reediciones y adaptaciones, ha suscitado numerosas investigaciones que a día de hoy conforman una extensísima producción académica y científica en torno a la obra caracterizada por su multidisciplinar naturaleza y su fuerte proyección a nivel internacional.

El presente documento no versa sobre la sociología de los textos (McKenzie, 1986), ni por tanto, tampoco quiere semejarse al debate acerca de la materialidad del texto y la textualidad del libro de Chartier (2006), simplemente acepta la afirmación de «que ningún texto existe fuera de las formas materiales que lo dan a leer u oír» (Scott, 2001: 117-118), para a propósito del paratexto, al que Graham (2000) atribuía una función especial como elemento de interconexión directa entre el lector y el libro, marcando los límites del texto (umbral) y a la vez enmarcando y constituyendo la obra para los lectores, es que consigamos descifrar un nuevo valor del Quijote como significante en la construcción de nuestra identidad nacional para el periodo señalado (1931975). En este punto, el estudio de las portadas de las adaptaciones escolares del Quijote entre la II República y el franquismo exige un planteamiento

11. Cabe recordar que «ya en los setenta, con una literatura infantil en franca expansión y nuevos parámetros sociales y educativos, las adaptaciones y versiones del Quijote para los niños se reubican, y encuentran su lugar en las bibliotecas, familias y contextos de lectura no escolares, en busca de nuevas formas para transmitir la historia del héroe manchego» (Sotomayor y Navarrete, 2005: 42). 
multidisciplinar, en el que tomando especial relevancia la Historia de nuestro país en materia política y educativa, nos influirán a su vez los conocimientos y aportaciones procedentes de la ciencia de la Historia Universal, la Historia de la Comunicación Social, la Literatura, el Arte, y los estudios relativos al diseño y la ilustración infantil, entre otros. No obstante, sin perder la perspectiva de que nuestra pretensión no excede de plantear una investigación de las portadas en tanto que actos comunicativos a las que cabe encomendar una serie de funciones de carácter persuasivo y comercial.

Las imágenes existen desde que el hombre es hombre y sus manifestaciones son tan variadas como numerosas. Forman parte del acervo cultural y se constituyen como un elemento indispensable para comprender los fenómenos culturales (Burke, 2001; Ramonet, 2000; Gauthiert, 1986; Baudrillard, 1978; Font 1981). Para poder comprender una imagen debe ponerse en relación con el contexto cultural en el que se produce en tanto que lo determina y conforma. Por consiguiente, este estudio iconográfico no va a limitarse únicamente a lo que manifiestan en sí mismas las portadas de las ediciones escolares del Quijote, sino que considerando el contexto social que les concierne, procurará una interpretación de los códigos comunicativos y semiológicos que apuntalan sus ilustraciones y otros mensajes en ellas inscritos, de diferente índole y valor, en virtud de esas circunstancias que los enmarcan. Esta es la principal razón por la que el total del periodo analizado (1931-1975) se subdivide a su vez, para la disposición de un marco teórico temporal adecuado al análisis del objeto de estudio, en varios períodos que en líneas generales engloban los tres momentos históricos más trascendentes desde un punto de vista político que entonces tuvieron lugar en España y que son la II República, la Guerra Civil, y la dictadura militar de Franco. Se tendrá en cuenta la influencia que puedan ejercer estos contextos sobre el tratamiento iconográfico de las portadas de las adaptaciones escolares del Quijote, valorando desde la disciplina de la Comunicación y en términos globales, si existió una impronta política real sobre las mismas o si por el contrario fueron elementos poco politizados en su caso.

La pertinencia de este estudio radica, por tanto, en el análisis de la paratextualidad de la obra cervantina desde un enfoque diferente que parte de la siguiente premisa:

La iconografía ya no es sólo paratexto, porque también ha de ser leída, descifrada, y porque constituye un modo de comunicación que refuerza, sustituye o implementa los mensajes formalizados. (Escolano, 1998: 134).

Y así, posicionados frente a la necesidad de investigar la capacidad comunicativa de la ilustración en la obra escolar cervantina para un periodo histórico concreto de nuestro país, construimos el valor epistemológico de nuestra investigación, defendiendo la hipótesis de que el estudio comunicativo del Quijote desde una perspectiva iconográfica e iconológica, a través de las portadas de las adaptaciones escolares de la obra durante dicho periodo (1931-1975), es revela- 
dor de la escasa o nula politización de la ilustración escolar más representativa del texto (la del peritexto o portada).

Así, el estudio atiende a las imágenes y su capacidad persuasiva (Eguizábal, 2007; Adam y Bonhomme, 2000; Frascara, 2006; Rodríguez, 2008; Brown, 2004) como aspecto básico y determinante de las portadas, que además de generar cierta admiración y respeto por su condición estética, cumplen con una función primordial al constituirse en una herramienta indispensable para reconstruir el pasado, ya que son producto del tiempo en el que fueron creadas, ofreciéndonos pistas sobre las cuales repasar con mayor acierto el sentido de los acontecimientos históricos, ya que el hecho de que puedan ser repensadas y evaluadas nos acercará a comprobar cómo estos han condicionado no solo la producción editorial de unas épocas frente a sus más inmediatas sucesoras, incluso la de nuestros días, afectando tanto a la realidad editorial como a la percepción social que gira en torno al Quijote.

Panosfky, E. (1939) consideró que las imágenes forman parte de la cultura y que, en consecuencia, no pueden ser entendidas en su totalidad si no se tiene conocimiento de esa cultura en la que se generan y consumen. El autor propuso un método de análisis que ha sido de aplicación en diferentes ámbitos de la investigación histórica. Panosfky supera la mera contemplación de las imágenes para profundizar en un análisis más complejo que comprenda tanto las causas como las consecuencias de las mismas, así como el significado en relación con el contexto histórico. Su método contempla tres niveles en la investigación de las imágenes tal y como queda reflejado en el siguiente cuadro:

\section{CUADRO 1}

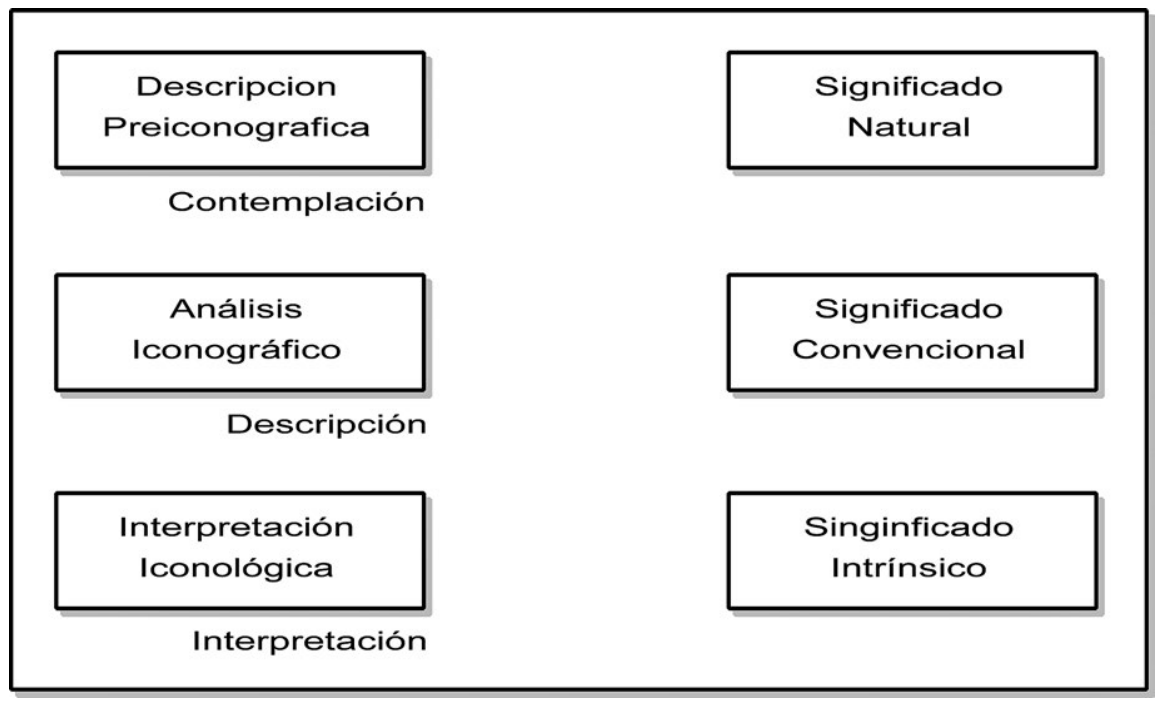

Fuente: Panosfky, E. (1980). 
Siguiendo esta tradición académica, nuestro trabajo se enmarca en los denominados estudios de análisis de contenido en tanto que aplicando este método a nuestro objeto de estudio podremos interpretar las imágenes y los textos que conforman las portadas de las adaptaciones escolares del Quijote bajo ciertas condiciones de organización y rigor.

La investigación se inicia con una primera fase de descripción -enmarcación, título, texto, imagen y color-y se culmina con una fase de interpretación y significación otorgada a las diferentes portadas objeto de análisis. Planteamos por tanto un estudio con dos partes complementarias pero claramente definidas: análisis cuantitativo y cualitativo (Cuadro 2).

\section{CUADRO 2}

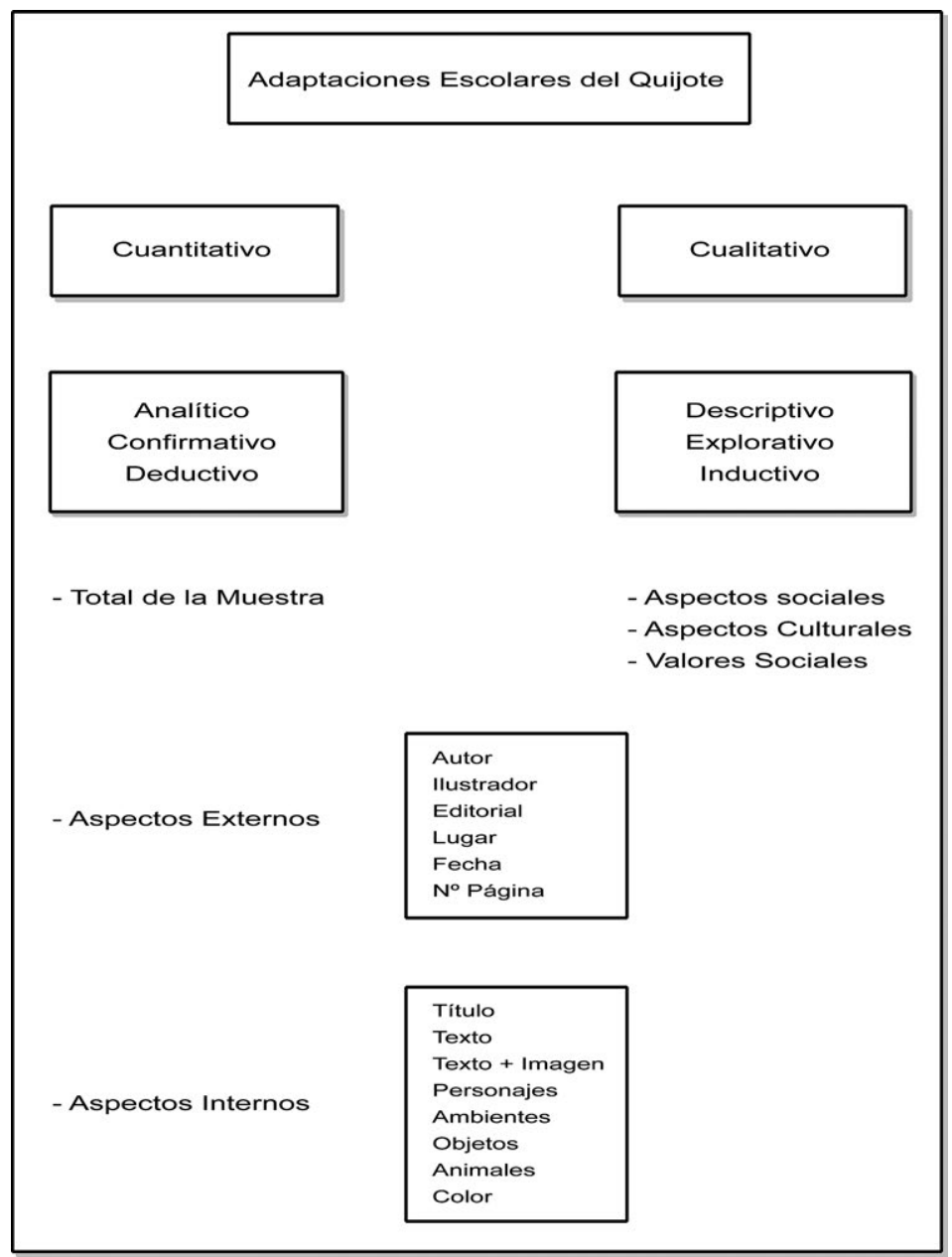

Fuente: Elaboración propia. 
Los análisis de contenido han sido profusamente empleados y cada vez tienen una influencia más significativa a la hora de abordar estudios de investigación relacionados con la comunicación, la historia y la educación. En el presente artículo abordamos una cuestión que, desde su particularidad, requiere contemplar, al menos, estas tres variables. Tal y como señala Bardin (1991: 29): «el propósito del análisis de contenido es la inferencia de conocimientos relativos a las condiciones de producción (o eventualmente de recepción) con ayuda de indicadores (cuantitativos o no)» y esta es precisamente nuestra pretensión al escoger este modelo de investigación.

Existen numerosos e importantes trabajos de investigación educativa y comunicativa que han utilizado con éxito el método de análisis de contenido y que han sido tomados en consideración para la elaboración del presente artículo, entre ellos destacamos las aportaciones de García (1983) sobre la ideología y la educación analizando libros de lectura en la escuela primaria; Anderson, (1987) sobre los estereotipos de género e imágenes de la familia, Sureda (1994) en el ámbito de las publicaciones escolares no periódicas; García (1993) sobre las estructuras y contenidos de textos escolares en la historia española; Colas y Corts (1990) en torno a las imágenes de los libros escolares; Martín (1996 y 2001) investigando la imagen de los textos escolares en la escuela franquista y de los libros de literatura escolares respectivamente; Atienza (1995-1996; 2007 y 2010) centrándose en la transmisión ideológica en los contextos educativos; y Rodrigo (2012) centrado en la transmisión de modelos sociales en la obra de Eduardo Vicente, entre otros.

La aplicación de esta metodología al análisis del objeto de estudio de nuestra investigación se llevó a cabo siguiendo un modelo estructurado en tres fases:

TABLA 1. Fases del Estudio

\begin{tabular}{|l|l|l|l|}
\hline \multicolumn{1}{|c|}{ Fase } & \multicolumn{1}{|c|}{ Estudio } & \multicolumn{1}{c|}{ Tarea } & \multicolumn{1}{c|}{ Finalidad } \\
\hline $1^{\text {a }}$ Fase & $\begin{array}{l}\text { Teórico } \\
\text { conceptual y } \\
\text { descriptivo }\end{array}$ & $\begin{array}{l}\text { Introducción al } \\
\text { objeto de estudio. } \\
\text { Presentación } \\
\text { del estado de la } \\
\text { cuestión. }\end{array}$ & $\begin{array}{l}\text { Determinar } \\
\text { el enfoque } \\
\text { adoptado en la } \\
\text { investigación } \\
\text { y establecer la } \\
\text { particularidad de } \\
\text { este estudio frente } \\
\text { a los anteriores. }\end{array}$ \\
\hline $2^{\text {a Fase }}$ & $\begin{array}{l}\text { Experimental } \\
\text { cuantitativo y } \\
\text { cualitativo }\end{array}$ & $\begin{array}{l}\text { Trabajo } \\
\text { Experimental }\end{array}$ & $\begin{array}{l}\text { Análisis y } \\
\text { resultados de la } \\
\text { muestra objeto de } \\
\text { estudio }\end{array}$ \\
\hline
\end{tabular}


TABLA 1. Fases del Estudio (Continuación)

\begin{tabular}{|l|l|l|l|}
\hline \multicolumn{1}{|c|}{ Fase } & \multicolumn{1}{|c|}{ Estudio } & \multicolumn{1}{c|}{ Tarea } & \multicolumn{1}{c|}{ Finalidad } \\
\hline $3^{\text {a }}$ Fase & Conclusivo & $\begin{array}{l}\text { Grado de } \\
\text { cumplimiento } \\
\text { de los objetivos } \\
\text { planteados en la } \\
\end{array}$ & $\begin{array}{l}\text { Comprobar } \\
\text { el papel } \\
\text { comunicativo que } \\
\text { desempeñaron las } \\
\text { investigación } \\
\text { portadas de El } \\
\text { Quijote }\end{array}$ \\
\hline
\end{tabular}

Fuente: Elaboración propia

Con el empleo de este modelo secuenciado conseguimos, en primer lugar, mediante el estudio teórico-conceptual definir y delimitar con rigurosidad el objeto de estudio. Mediante la segunda de las fases, el estudio experimental nos permitió analizar la muestra seleccionada, desde un punto de vista tanto cuantitativo como cualitativo, y vislumbrar de forma preliminar las posibles conexiones existentes entre ellos. En la tercera y última fase, la conclusiva, mediante la estadística y la inferencia, se han podido relacionar coherentemente los datos obtenidos para alcanzar las denominadas «variables inferidas», que aportan los conocimientos relativos a la ideología y otros aspectos sociales, culturales, económicos y políticos, que constituyen los valores más significativos que destacar desde el enfoque comunicativo adoptado en esta investigación.

\section{LAS ADAPTACIONES ESCOLARES DEL QUIJOTE ENTRE LA II REPÚBLICA Y EL FRANQUISMO. PRESENTACIÓN DE LA MUESTRA Y EL ANÁLISIS}

El estudio experimental de la presente investigación se enmarca en el análisis de un corpus de ediciones escolares del Quijote compuesto por 51 portadas correspondientes a las publicaciones de este tipo que tuvieron lugar entre los años 1931 y 1975, entre la II República y el Franquismo. Se trata de un corpus extenso y completo, extraído de la exposición bibliográfica de ediciones del Quijote para niños y jóvenes que se celebró en 2005 con motivo de la presencia de España en la Feria Internacional del Libro Infantil y Juvenil de Bolonia, y que comprendía una recopilación mucho más amplia que la muestra aquí analizada correspondiente al periodo comprendido entre los años 1856 y 2000. Bajo dicha circunstancia el estudio queda delimitado rigurosamente sobre la base de una muestra proveniente de la anterior y acotada para los años señalados (1931-1975), que al encontrarse previamente localizada y catalogada constituye un exhaustivo ejemplo de la adaptación escolar de la obra cervantina, y permite así garantizar la satisfacción de los objetivos, tanto desde el punto de vista formal (atendiendo a las técnicas de expresión manifiestas) como del contenido, sirviendo a la consecución de nuestros principales propósitos. 
Los libros de lectura en general, y El Quijote en particular, han estado y permanecen en la actualidad presentes en los centros de enseñanza constituyendo un instrumento muy valioso para expresar las actitudes, valores y modos de pensar y sentir de la sociedad, así como de las ideologías establecidas y las mentalidades dominantes. Quizá sea por este último motivo por lo que han recibido la atención de todos los poderes públicos que bajo diferentes regímenes políticos han tratado de regular y controlar las lecturas que se disponían en los centros escolares. «Los libros escolares han sido siempre un producto cultural intervenido políticamente» (Escolano: 1992-17).

Visto así, para el estudio planteado, se ha considerado previamente atender a esa politización del libro escolar, llevando a cabo una división histórica más concreta para la presentación de la muestra de las adaptaciones escolares seleccionada, que respetando los márgenes del período analizado (1931-1975), permita observar cuál sería su relación, por ese orden cronológico, con las manifestaciones políticas y culturales que tuvieron lugar respecto de la intervención del libro escolar para ese momento de la historia analizado. De este modo, se establecen 5 períodos claramente diferenciados en función del momento histórico y de la relevancia de las políticas educativas que condicionaron la publicación de textos escolares, teniendo una mayor repercusión. Para ayudar en la visibilidad, lectura y comprensión de todos estos contenidos relacionados con la muestra de las adaptaciones escolares seleccionada hemos diseñando una serie de tablas dentro de las cuales confluyen todos los conocimientos separados en función de los correspondientes periodos.

\section{Periodo 1 (1931-1936)*}

Existe una gran preocupación política por modernizar los sistemas educativos. Creación de las Misiones Pedagógicas con las Bibliotecas Populares.

El Consejo de Instrucción Pública efectúa la aprobación de los libros de texto (1932).

Se realiza la primera selección de obras para la etapa primaria (1934).

La política republicana sobre textos escolares se interrumpió drásticamente con el comienzo de la Guerra Civil
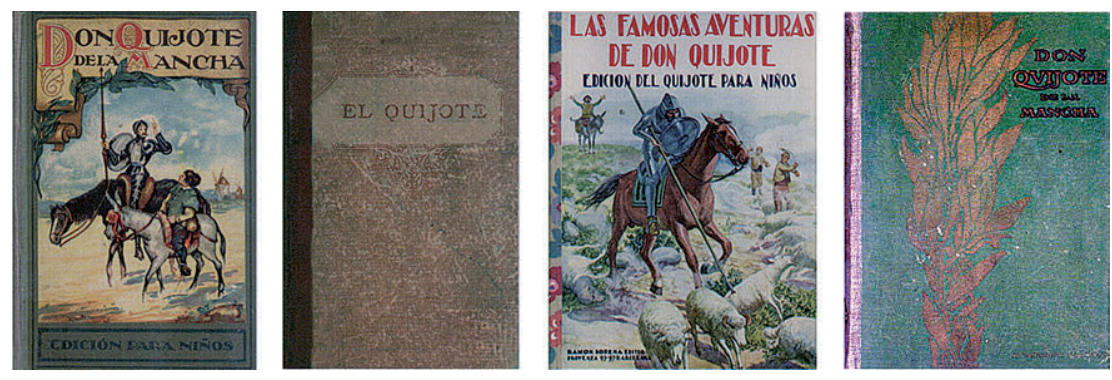

* Este periodo finaliza el 18 de julio de 1936 fecha del golpe de estado denominado por el bando fascista como Alzamiento Nacional que da comienzo a la Guerra Civil. 
Periodo 2 (1936-1939)*

Fiscalización de los libros escolares (1936)

Depuración de las bibliotecas públicas (1937)

M. Reyero presenta una selección de veinte libros que fueron seleccionados como los más idóneos para su uso en las escuelas, entre ellos figura El Quijote. (1937)

Instrucción primaria sobre la edición del «Libro de España» (1937)

Comisión dictaminadora de libros para las escuelas (1938).
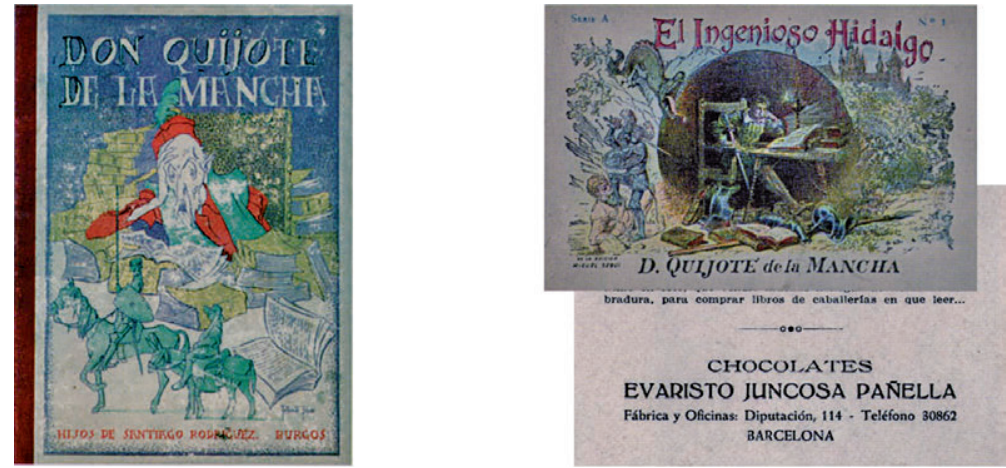

* El periodo comprende entre el 18 de julio de 1936 hasta el 1 de abril de 1939, fecha del último parte de guerra en el que se anuncia oficialmente la finalización del conflicto armado.

La organización de la muestra en función de estos períodos, permitió, mantener en todo momento la atención sobre los datos históricos más relevantes que guardan una relación indiscutible con el proceso editorial de las adaptaciones escolares del Quijote y consecuentemente con la configuración de las portadas, lo que junto al análisis de contenido ha supuesto datos significativos que no solo reafirman y convergen con los axiomas vertidos por otros autores al hilo de la instrumentalización del Quijote (Guereña, 2008) en las escuelas, o de la importancia de su iconografía para su constitución en un símbolo nacional, sino que darán luz a otras afirmaciones acerca de la labor editora e ilustradora realizada sobre las adaptaciones para la comunicación comercial de la obra escolar cervantina sobre la creación de una identidad corporativa universalmente reconocible más allá del ámbito educativo.

Dicho análisis de contenido se diseñó siguiendo un modelo de dos fases diferenciadas desde las que abordar el objeto de estudio. Así, en una primera fase, que denominamos «Fase Externa», se recopilan los datos de carácter formal de las ediciones que figuran en el siguiente cuadro:

En una segunda fase, denominada «Fase Interna», dividimos la muestra para su estudio entre ejemplares tipográficos y ejemplares ilustrados, atendiendo a diferentes variables de forma pormenorizada con especial énfasis desde el punto de vista iconográfico. 


\section{Periodo 3 (1939-1958)*}

Relación de libros aprobados por la comisión dictaminadora de libros escolares (1939)

Se suprime el Museo Pedagógico y sus fondos se integran en el Instituto de Pedagogía San José de Calasanz (1941)

Ley de Educación de la escuela al servicio de la religión y de la patria (1945) Formulación de los primeros cuestionarios nacionales de enseñanza primaria que no incluyen ninguna novedad en lo referente a los textos escolares.
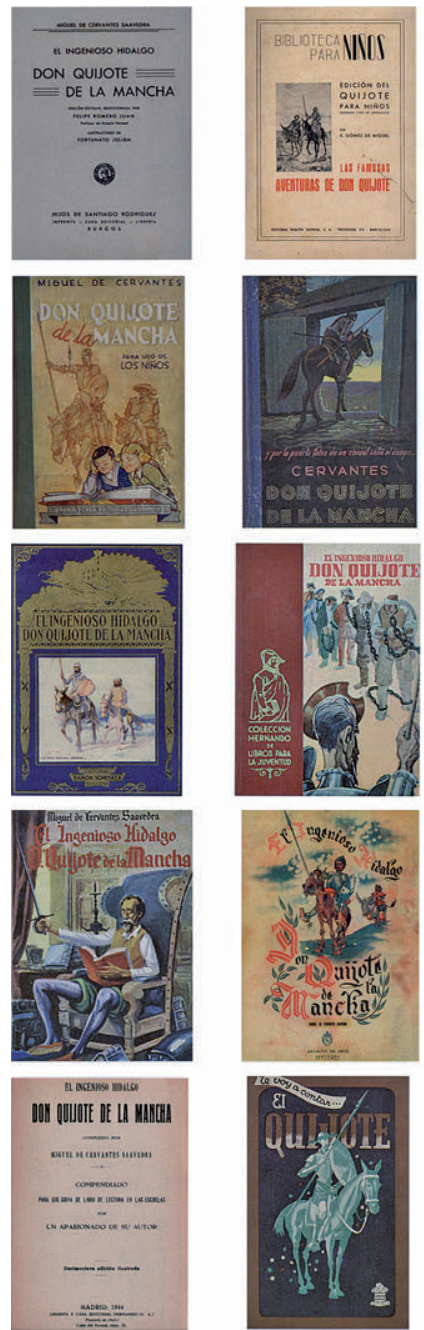
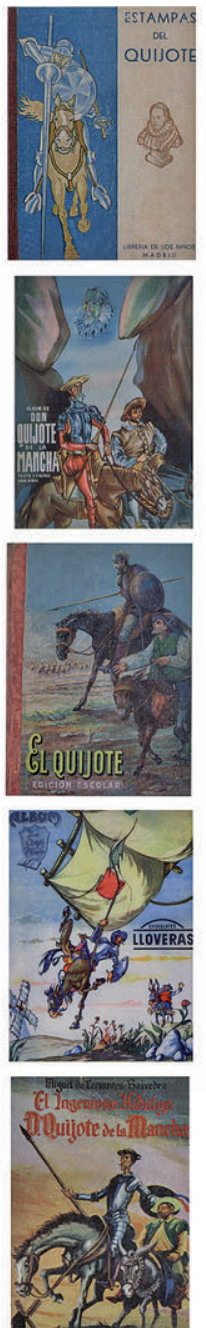
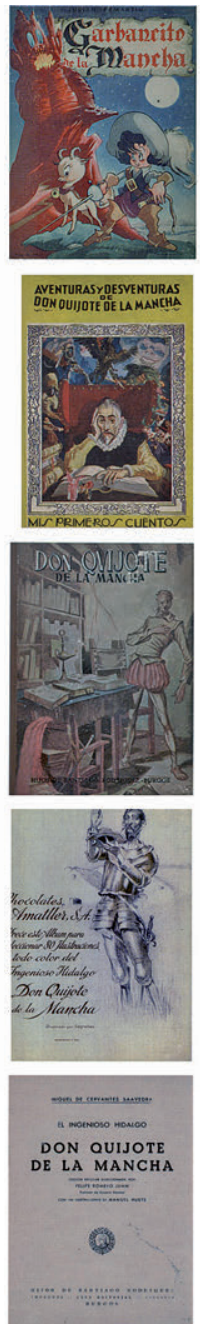
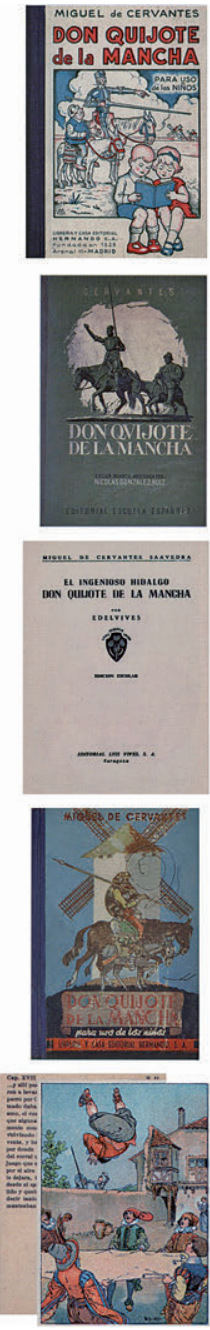

* El tercer periodo se inicia el 2 de abril de 1939, primer día sin guerra y finaliza el 15 de mayo de 1958 con motivo de la creación del CEODEP. 


\section{Periodo 4 (1958-1965)*}

Creación del CEODEP Centro de orientación y Documentación Didáctica de Enseñanza Primaria (1958)

Aprobación de las primeras normas materiales y pedagógicas a las que deberían ajustarse los libros escolares para su homologación (1958)

Los libros de religión deberán superar también la censura eclesiástica, así mismo, los textos relativos a la formación del espíritu nacional, las enseñanzas del hogar y la educación física deberán contar con el visto bueno favorable del Frente de Juventudes o de la Sección Femenina según se dirigiesen a alumnos o alumnas.

El CEODEP garantizaba la calidad técnica de los libros escolares mientras que la Iglesia y el Frente de Juventudes y la Sección Femenina vigilaban la pureza ideológica. (1958)

Se especifican, con todo lujo de detalles, las características que debían reunir los textos escolares. (1960)
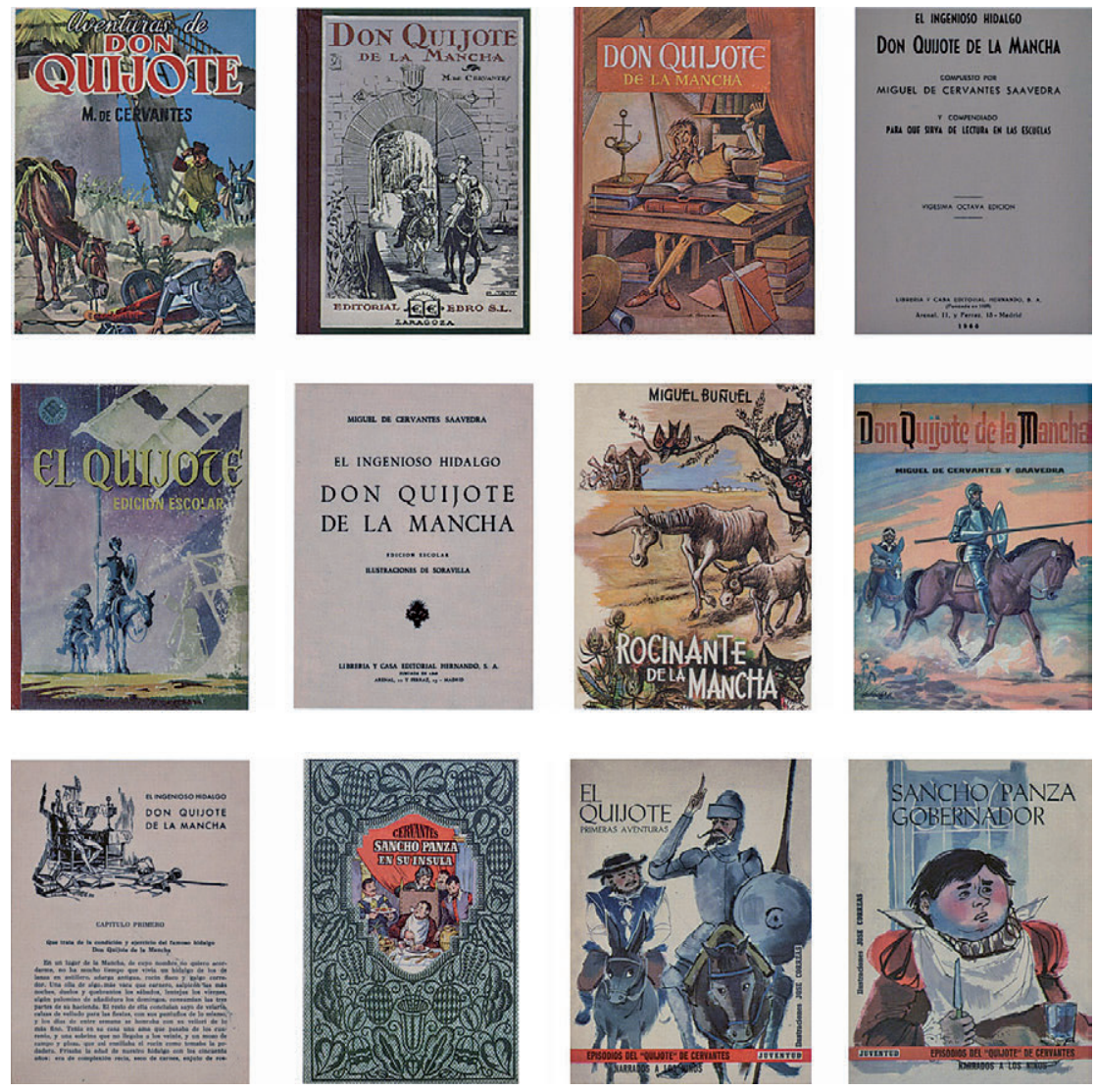

* Este periodo se inicia con la creación del CEODEP y finaliza el 23 de septiembre de 1965 fecha en la que se aprueba la formulación de los nuevos cuestionarios de educación primaria. 


\section{Periodo 5 (1965-1975)*}

Publicación de los nuevos cuestionarios que obligan a revisar todos los textos y manuales escolares que se utilizaban en las escuelas. Se establecen los requisitos para su adaptación a los nuevos cuestionarios y la elaboración de libros por cursos y materias. (1965)

La revista Vida Escolar, en su $n^{\circ}$ 89-90 dedica un monográfico a los manuales escolares. (1967)

Publicación de la Ley General de Educación de Villar Palasí. Ley que abre un proceso de innovación y cambio en nuestro sistema educativo. (1970)

Se reserva al MEC la aprobación de textos escolares suprimiendo el dictamen del Consejo Nacional de Educación. Esta situación ha sido denominada por Escolano, A. como la época de una nueva generación de textos escolares. (1971)
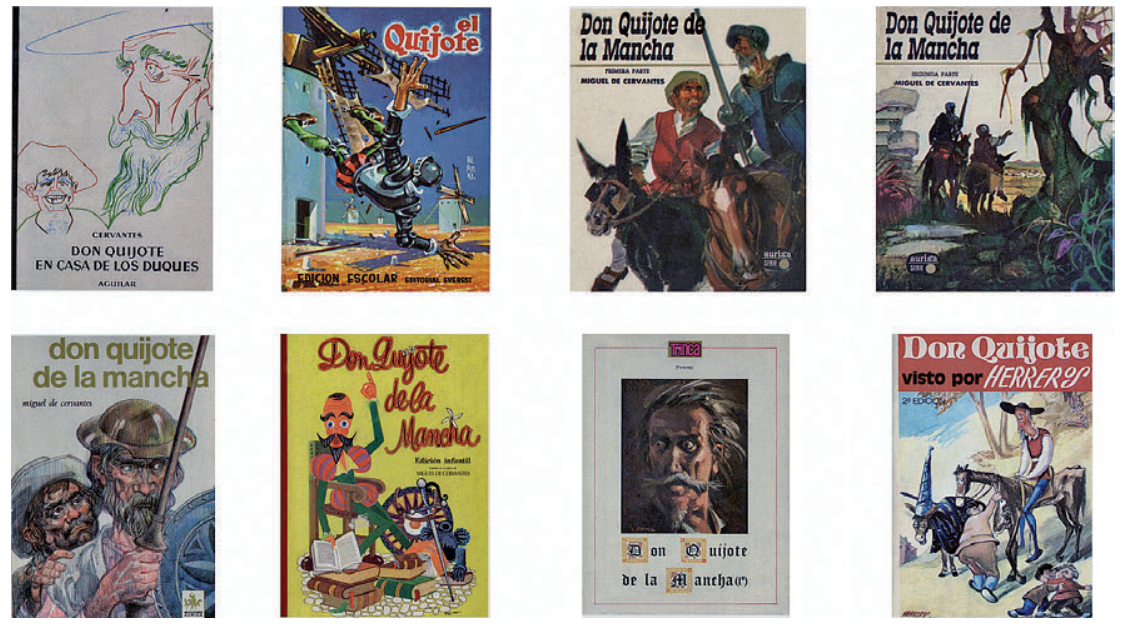

* El último periodo comprende desde la aprobación de los nuevos cuestionarios de educación primaria en septiembre de 1965 y finaliza el 20 de noviembre de 1975 con la muerte del Francisco Franco.

\section{CUADRO 3}

\section{Fase Externa}

- Autor de la adaptación

- llustrador

- Editor

- Lugar

- Fecha

- Número de páginas

Fuente: Elaboración propia. 


\section{CUADRO 4}

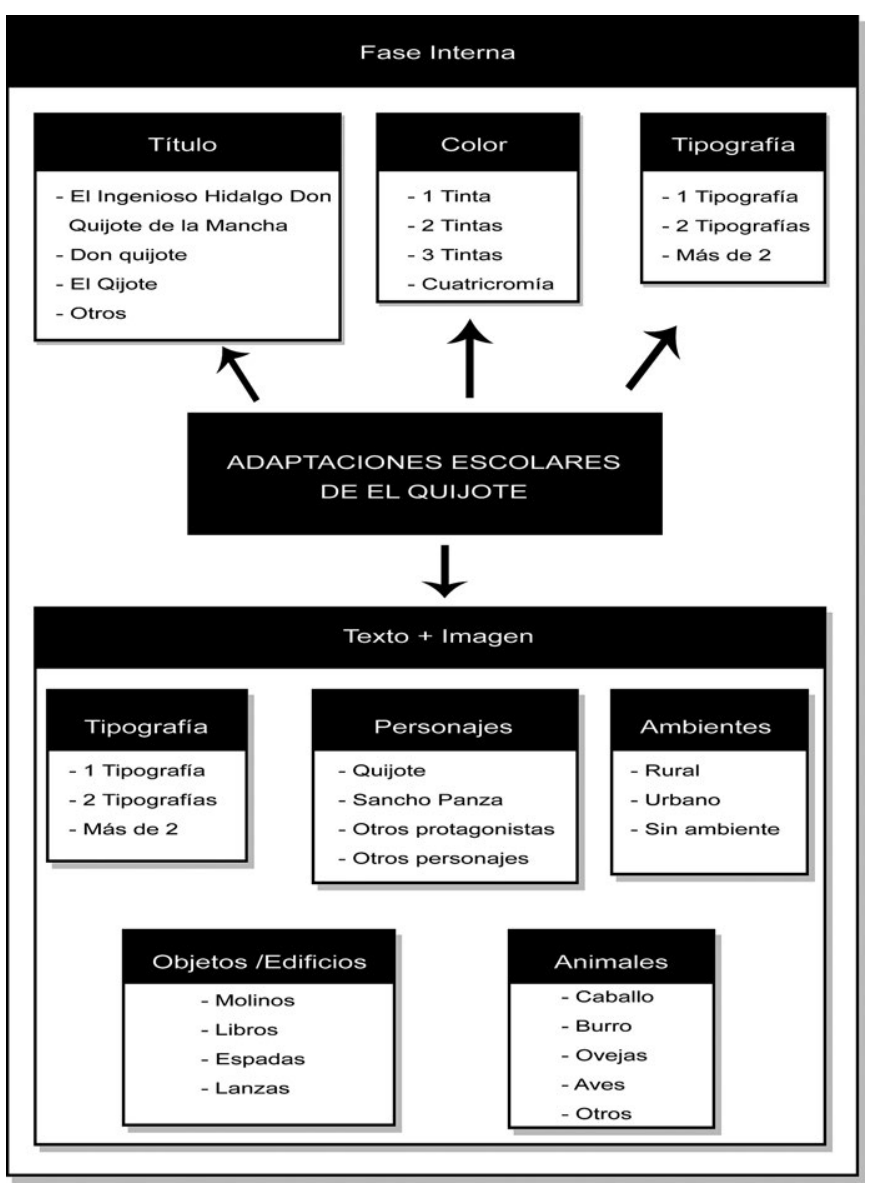

Fuente: Elaboración propia.

\section{RESULTADOS E INFERENCIAS PRELIMINARES DERIVADAS DEL ESTUDIO DEL QUIJOTE ESCOLAR (1931-1975)}

Gracias a la fragmentación anterior por períodos del momento histórico que comprende la II República y el Franquismo -reflejada a través de la exposición de las tablas-, hemos podido satisfacer positivamente la primera de las obligaciones que ha de considerar un trabajo de estas características, al poder recopilar de forma sencilla y esquemática el compendio de hechos históricos que atestiguan el intervencionismo político de la educación en nuestro país. De este modo, hemos focalizado la recopilación de toda la información más relevante adaptándola a los intereses de la investigación y escogiendo de entre los datos aquellos determinantes en el tratamiento que recibió el libro escolar 
y muy especialmente los de lectura - por englobarse dentro de su categoría la obra que aquí estudiamos-, y porque además su volumen en las escuelas siempre fue superior frente al resto de textos dispuestos para la enseñanza, de ahí que fueran objetivos prioritarios de las políticas de control educativo, como sucedió en el caso de Don Quijote de la Mancha, por cuantas particularidades acogió entonces su adaptación para la lectura durante la etapa primaria de la enseñanza.

Dada la extensión excesiva que supondría la exposición total y rigurosa de los datos procedentes del análisis de contenido realizado, vamos a continuación a explicar cuál ha sido el procedimiento llevado a cabo para posibilitar la extracción de los fundamentos e inferencias más relevantes, que se han realizado en un intento de contribuir a la ampliación de miras sobre el estudio académico y científico multidisciplinar que permite la obra cervantina, y que ya es un hecho constatado.

Esta investigación partió de la hipótesis de que la intervención del libro escolar, o dicho de otro modo, las políticas en materia educativa que tuvieron lugar durante la II República y el Franquismo, en lo que a la adaptación escolar de la obra cervantina se refiere, no ejercieron el adoctrinamiento ideológico pretendido de forma precisa, al obviar intervenir consecuentemente la portada de esas adaptaciones pedagógicas dirigidas al público infantil, lo que derivó en una divulgación continuada de la obra principalmente útil para su popularización como icono nacional con independencia de las ideologías dominantes.

En términos generales, y teniendo muy presente que el objetivo de nuestro análisis ha sido medir las constantes iconográficas desde una perspectiva comunicativa que caracterizaron la edición y adaptación escolar del Quijote (1931-1975), y que transcendieron del terreno más puramente ideológico comunicando la obra con su público mediante la creación de todo un símbolo nacional y referente patriótico, sirva aclarar que las aportaciones resultantes de la tarea investigadora se interpondrán con carácter global respetando el orden de procedencia de los datos, pudiendo concretarse en dos puntos claramente diferenciados; primero, las derivadas del análisis de contenido en su fase externa, prosiguiendo posteriormente con las otras relativas a la fase interna. De igual modo, y aunque no ha sido objetivo de esta investigación el establecimiento de diferencias y semejanzas entre los dos regímenes antagónicos que protagonizan el período analizado, en ocasiones se establecen ciertos matices referentes a la situación política cuando los resultados son merecedores de puntualizaciones en este sentido, bien porque las connotaciones específicas de esta índole interfieren en su interpretación o la información última que nos reportan.

Conforme a la fase externa, conviene comenzar destacando la labor de las editoriales que más adaptaciones escolares del Quijote realizaron entre la II República y el Franquismo. Cuantitativamente, de la muestra seleccionada, es la editorial Hernando (Madrid), con siete ediciones, la que mayor cantidad de adaptaciones presenta, seguida de Hijos de Santiago Rodríguez (Burgos) con seis, y la editorial Ramón Sopena (Barcelona) que cuenta con cuatro obras; 
así, existen un total de otras 18 editoriales más. Desde un punto de vista cualitativo, valga la pena señalar que todas las adaptaciones están realizadas por editoriales de nacionalidad española, con la única excepción de la Editorial Molino que tiene sede en Buenos Aires (Argentina). En parte, esto puede ser interpretado como una circunstancia derivada del origen autóctono de la obra objeto de la adaptación, claramente española, y de otra de la tradición del sector editorial español desde antes de la Restauración en el mercado escolar, dado que siempre fue uno de los más atractivos económicamente ${ }^{12}$. No obstante, de las 51 ediciones sometidas al análisis, tan sólo 4 tienen lugar durante la República, 2 ediciones en la Guerra Civil, mientras el resto (45) se corresponden con ediciones cronológicamente vinculadas a la dictadura franquista. Resulta igualmente llamativo que de las editoriales destacadas por presentar una mayor producción, tan solo Sopena e Hijos de Santiago Rodríguez pueden presumir de haber editado adaptaciones escolares del Quijote tanto en la II República como en el Franquismo ${ }^{13}$.

En esta fase también se acude a recopilar información relativa a los autores de las adaptaciones contenidas en la muestra, aunque se trate de un dato que no siempre se refleje en las portadas, lo cual es significativo de algún modo, del todavía escaso reconocimiento que en este sentido tenía la labor de estos sobre el valor final de la obra adaptada, en la que lo realmente importante era reconocer a Cervantes y su excelso trabajo. Lo mismo sucedía con los ilustradores, aunque iban ganando cuotas de reconocimiento paulatinamente mayores, que dejaban atrás los tiempos en los que su trabajo caía en el anonimato. Una vez más, desde un punto de vista cuantitativo, de entre los autores resalta por el número de colaboraciones el nombre de Felipe Romero de Juan, que es sin duda el más destacado, con una total de seis adaptaciones; mientras, y atendiendo también a su participación múltiple en este sentido, los autores Gómez de Miguel, Miguel Toledano, Gloria Sarró y Fernando Castro, firman dos obras cada uno a lo largo del período completo objeto de análisis; por último, señalar que son otros 18 autores más los que completan la muestra. Y como habíamos avisado, el panorama es muy similar con respecto de los ilustradores, siendo Palau, Fortunato Julián, Manuel Huete y José Llobera los que mayor número de trabajos registran, con tres obras cada uno, además de otros 21 ilustradores más. Desde un punto de vista cualitativo, puede precisarse que el trabajo vinculado al mundo del libro escolar fue una labor

12. Sin embargo, otra interpretación posible tiene que ver con el carácter autárquico de la política económica que impuso el régimen fascista, durante el cual tiene lugar la mayor parte de la producción editorial de Quijotes escolares, al tratarse de un periodo tan extenso en el tiempo y que supuso el aislamiento internacional de España hasta bien entrados los años cincuenta.

13. Cabe mencionar a este respecto la tirantez comercial entre editoriales, docentes y librerías existente durante la guerra civil, y cuyo testimonio reflejaron las quejas interpuestas por los libreros en 1939 ante la Comisión Dictaminadora de los Textos de Enseñanza Secundaria contra los catedráticos de instituto que no les distribuían sus obras para vendérselas directamente a sus alumnos (Sureda, 1997: 92). Una circunstancia que, sumada a la tan adversa coyuntura política que atravesaba el país, pudo contribuir a la mayor desestabilización del sector editorial. 
notablemente masculina durante todo el período, con independencia una vez más, de que fuera el régimen republicano o franquista el que gobernase ${ }^{14}$. De hecho, de entre todos los autores e ilustradores, tan solo aparecen los nombres de dos mujeres: Gloria Sarró, autora de las adaptaciones de 1967 y 1968 de AFHA Internacional, y Nydia Lozano autora e ilustradora en colaboración con Leopoldo Sánchez de la adaptación de la Editorial Doncel en 1973. Además, destaca el hecho de que las contribuciones de ambas mujeres a la obra cervantina tengan lugar en los años finales del período analizado coincidiendo con la etapa tecnócrata que sirvió a la modernización de la Educación en España, y no anteriormente.

Al poner en relación la labor de editoriales, autores e ilustradores, se percibe que la labor editorial en torno a la adaptación escolar del Quijote se caracteriza por la gran multiplicidad de los actores productores y editores, siendo escasos los trabajos compartidos por los mismos autores e ilustradores que perduran en el tiempo, incluso ya no sólo en lo relativo a las colaboraciones conjuntas realizadas entre ellos, sino también con respecto de la misma editorial. En este caso, la editorial Sopena tan sólo cuenta con dos ediciones en las que autor e ilustrador repitan colaborando conjuntamente, como es el caso de las correspondientes a los años 1932 y 1942; Hijos de Santiago y Rodríguez llega a presentar como récord un máximo de hasta tres ediciones realizadas repetidamente por Felipe Romero y el ilustrador Manuel Huete (1951, 1957 y 1961); son dos colaboraciones también las firmadas por Miguel Toledano y José Correas en la editorial Juventud para un mismo año (1964); AFHA Internacional en su caso, destaca por las ediciones de 1967 y 1968 adaptadas por Gloria Sarró y con dibujos de Llobera, que después para 1971 repite como ilustrador pero en otra adaptación realizada por Antonio Cunillera; por último, la editorial Hernando presenta dos ediciones relativas a un mismo autor, las de Fernando de Castro de 1943 y 1944, pero con ilustradores diferentes, y asimismo, con otras dos ediciones participadas por el mismo ilustrador Rosado Rivas y diferentes autores.

Una tendencia que muestra como advertíamos la concurrida y variada actividad adaptadora e ilustradora del Quijote en el período analizado, a pesar de la escasez económica reinante, la todavía baja calidad de los materiales y el coste importante que suponían las labores de impresión, que debido a la importancia que comienza a cobrar el color incidiría en el precio de venta final de las adaptaciones escolares (Beas y Montes, 1998), hasta el punto de que dicha circunstancia invitó a su control a los distintos gobiernos de España. Especial mención merece en este sentido el análisis realizado de la muestra al objeto de comprobar el tamaño de estas adaptaciones escolares, por cuanto su grosor influía también en el precio, y que se destinaban a los maestros para el desempeño de sus funciones pedagógicas. Así, los datos

14. Para más información sobre la influencia de los regímenes políticos en la actividad ilustradora véase de nuevo Tiana Ferrer (1997). 
muestran la disparidad de las adaptaciones con respecto de ese su principal objetivo. La obra más voluminosa contiene 1048 páginas y corresponde a la edición de 1948 que la editorial Ramón Sopena (Barcelona) realizó con motivo del IV centenario del nacimiento de Cervantes, con una portada verdaderamente lujosa. De gran tamaño son también las adaptaciones de Razón y Fé de 1945 con 1026 páginas, y las de Saturnino Calleja, Dalmau y Hernando de 726, 651 y 500 páginas, respectivamente. El grosor de estas obras es un claro indicativo de la polémica que suscitaría la lectura del Quijote en las escuelas ${ }^{15}$, pues además, cabe enfatizar como otra conclusión importante que las largas ediciones fueron una constante con aprobación por parte de los dos regímenes políticos encontrados durante este período. Así, aunque la obra más voluminosa como hemos señalado es la Sopena de 1948, con 1048 páginas, y por tanto editada durante la dictadura franquista, y a pesar de las pocas adaptaciones que se publicaron durante la II República, -también por ese corto espacio de tiempo que la define respecto del tiempo político ulterior-, resulta igualmente notorio que de las seis ediciones publicadas durante su gobierno, dos se sitúen por encima de las 700 y las 600 páginas, y otras dos por encima de las 300. Una vez más, puede afirmarse, que teniendo en cuenta que eran los niños los principales lectores a los que se dirigían las adaptaciones, todo parece indicar respecto de estos grandes volúmenes que su aprobación más bien respondía a un primer objetivo, que no era tanto su comprensión por parte de su público objetivo, sino la introducción del texto de forma incuestionable en la escuela como elemento de enseñanza indispensable para el adoctrinamiento político y la instrucción de los valores ideológicos imperantes. Y así es que en general, la adaptación al ámbito educativo de la obra cervantina en esos años se presenta abundante, dado el alto número de adaptaciones editadas, sobre cuyos tamaños cabe decir también que hay una mayoría de ejemplares que oscilan entre las 80 y las 47 páginas de media, y por tanto, a priori más coherentes con ese objetivo de propiciar una lectura asequible de la obra en la etapa primaria de la enseñanza.

El análisis de las variables internas se ha centrado directamente en el estudio exclusivo de los elementos que componen las portadas de la muestra seleccionada. Para abordar esta tarea hemos tomado en consideración analizar de manera individual cada portada atendiendo a la interrelación que cada uno de los elementos guarda con su conjunto, considerando múltiples indicadores, y dividiendo la muestra para su análisis en dos categorías de portadas claramente diferenciadas: los ejemplares tipográficos (sin imagen) y los ejemplares ilustrados.

En la siguiente serie de gráficas presentamos los datos cuantitativos obtenidos en análisis de las variables internas: 


\section{CUADRO 5}

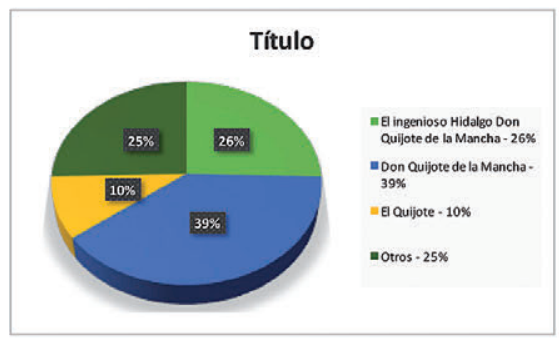

1

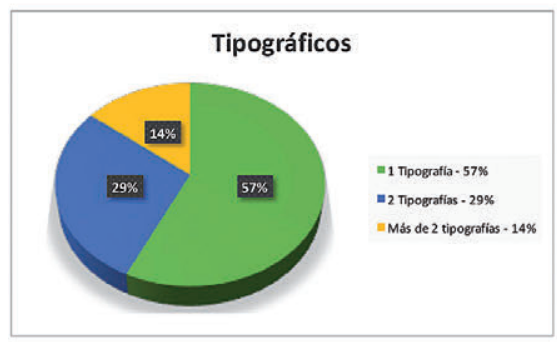

3

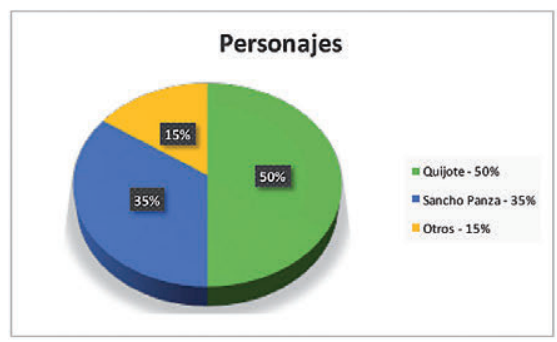

5

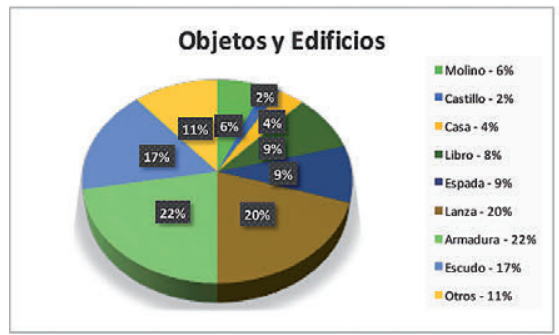

7

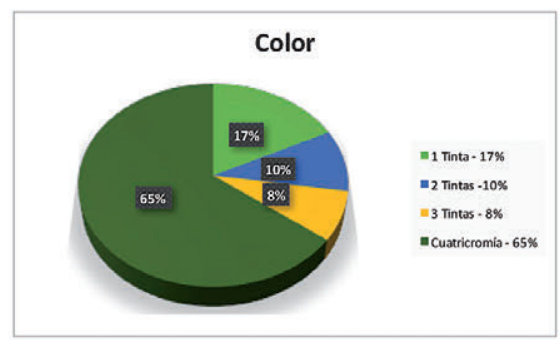

2

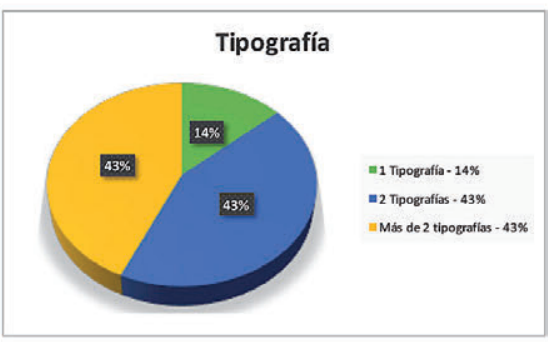

4

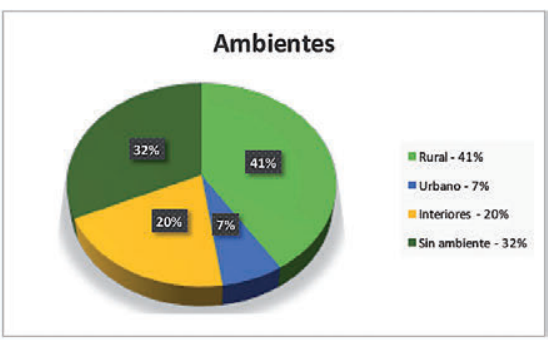

6

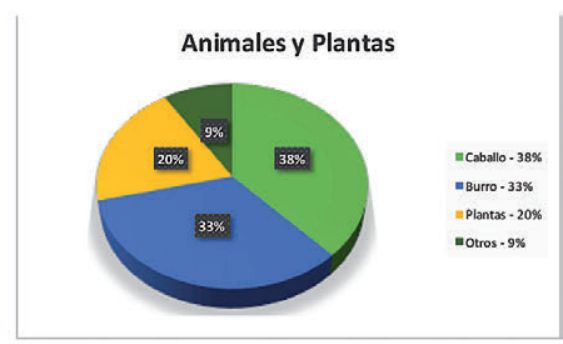

8

Fuente: Elaboración propia. 
En lo referente al título (gráfica 1) de las obras, constatamos que hay cierta variedad de títulos utilizados:

Don Quijote de la Mancha (20)

El Ingenioso Hidalgo Don Quijote de la Mancha (13)

El Quijote (5)

Las famosas Aventuras de Don Quijote (2)

Estampas del Quijote (1)

Garbancito de la Mancha (1)

Aventuras y desventuras de Don Quijote de la Mancha (1)

Te voy a contar el Quijote (1)

Aventuras de Don Quijote (1)

Sancho Panza en su Ínsula (1)

Rocinante de la Mancha (1)

El Quijote, Primeras aventuras (1)

Sancho Panza Gobernador (1)

Don Quijote en casa de los duques (1)

Don Quijote visto por herreros. (1)

La variedad de títulos, desde el punto de vista de la comunicación publicitaria, es un claro indicador del intenso bagaje comercial vinculado a la edición de esta obra, asombrosamente al margen de un momento histórico poco o nada boyante desde el punto de vista económico, y en el cual existe gran afán por ejercer una vigilancia política e ideológica de la sociedad desde un control importante y claramente manifiesto de la producción cultural, no sólo de libros, sino relativa a cualquier industria de esta índole. Así la variedad de títulos que suscita la adaptación escolar de la obra cervantina, puede tener también una explicación en términos comunicativos, que aludiría al hecho de hacer la obra más atractiva para los niños en tanto que son lectores primero potenciales y luego reales.

El estudio del color (gráfica 2) pone de manifiesto que la cuatricromía era la técnica cuyo uso estaba más generalizado alcanzando el 65\% de las portadas que conforman nuestra muestra. La utilización de una única tinta presenta un $17 \%$ de las portadas analizadas, mientras que la combinación de dos tintas se aprecia en un $10 \%$. Por último, la técnica menos utilizada es la combinación de 3 tintas que apenas alcanza el 8\% de la muestra objeto de análisis. El recurso del color no es un elemento que debamos menospreciar cuando está más que demostrado que su uso supone un aliciente considerable de cara a la motivación para la lectura que procura en las primeras etapas de la educación tanto infantil como primaria (Martín Requero, 1996). Además, los datos obtenidos en lo referente al uso del color confirman la importancia que todas las editoriales, y a lo largo de todo el periodo investigado, conceden a la portada por su alto valor comunicativo, persuasivo y seductor. Esto que es así para las portadas, no se cumple en el interior de los libros, sitio en el cual las ilustraciones frecuentemente se realizan a una sola tinta (negro), predominando el efecto óptico del blanco (del papel) y negro. 
En un primer acercamiento al análisis de las portadas encontramos, a simple vista, dos tipos claramente diferenciados de ediciones, aquellas cuya portada tan sólo presenta un color de fondo y las tipografías relativas a los datos externos más relevantes (título y autor) y que hemos denominado ediciones tipográficas; mientras que de otra parte, nos encontramos con aquellas ediciones que combinan la tipografía con la imagen ilustrativa y que hemos denominado ediciones ilustradas. Así, del total de la muestra, son solo ocho los ejemplares tipográficos frente a los 43 ejemplares ilustrados publicados a lo largo de todos los años comprendidos entre la II República y el Franquismo. Un análisis más completo, que intercala la importancia de los datos cualitativos con otros cuantitativos, referido a la variedad tipográfica de las portadas (gráfica 3) de las adaptaciones escolares de la obra de Cervantes nos acerca nuevos resultados: el 57\% utiliza una única tipografía, mientras que el $29 \%$ emplea dos y el 14\% restante más de dos.

En cuanto al grupo de los ejemplares ilustrados ha sido necesario precisar más las variables objeto de análisis, de cara a una mayor recopilación de información que posibilitase dilucidar de manera más exhaustiva el valor iconográfico de las ilustraciones, permitiéndonos inferencias más concisas y pertinentes, desde el punto de vista comunicativo. Para ello, se han incluido en el análisis las siguientes variables: tipografía, personajes, ambientes, objetos y edificios y animales y plantas.

En relación a las tipografías (gráfica 4), la variedad en el uso sigue siendo la constante más visible durante todo el periodo. Así, destaca que el $43 \%$ de las editoriales utiliza más de dos tipografías diferentes, mientras que el 14\% tan solo utiliza una, y el restante $43 \%$ de obras presentan una combinación de dos tipografías. Desde el punto de vista de la edición del libro y de la comunicación efectiva de la obra a través de esa primera toma de contacto que nos ofrece la portada, importa aclarar que la utilización de diferentes familias tipográficas supone en el momento de la edición un recurso intencionado para diferenciar con mayor claridad el título, del autor y del resto de datos escritos que aparecen en las portadas.

Muy interesante ha sido el estudio de los personajes (gráfica 5), reforzando la imagen mental iconográfica que culturalmente ha trascendido hasta la actualidad del Quijote, poniendo de manifiesto el protagonismo del personaje principal, el famoso Hidalgo, que se encuentra presente en el 50\% de las portadas analizadas, seguido de Sancho Panza que aparece en el 35\% de las mismas. El resto de ilustraciones objeto de las portadas aluden a otros personajes de la obra, hasta incluirse en algunas ediciones representaciones visuales de personas no intérpretes directos de la historia, fuera de sus más estrictos márgenes narrativos, como es el caso de las ediciones que recurren a las estrategias de desbordamiento (Díaz, 2003) en la ilustración para mostrar de manera complementaria a la imagen principal otra imagen, la de unos niños leyendo, en su mayoría niño junto a niña, como fórmula desde la que buscar una implicación más directa de esos sus lectores potenciales. Una forma, sin duda, de persuadir al consumo de la obra mediante la motivación que genera la comunicación de este tipo de 
imágenes, que utilizadas al más puro estilo publicitario (intencionadamente o no) sirven para ejercer una influencia determinada en el comportamiento del consumidor potencial, que favorezca al anunciante (en este caso, la editorial responsable de la publicación) su identificación con el producto, a imagen y semejanza de como lo haría una marca potente en la actualidad bajo el nombre de las denominadas estrategias de posicionamiento basadas en el usuario ${ }^{16}$.

Por su parte, el análisis realizado de los ambientes representados en las portadas (gráfica 6) ha procurado datos que evidencian que las escenas de los ambientes exteriores, referentes a zonas rurales o campos, tienen un peso considerablemente mayor (41\%) respecto de las de tipo urbano (7\%). En cuanto a los ambientes interiores y relativos a espacios dentro de casas, fondas y castillos, un $20 \%$ de las portadas incluye alguna ilustración de este tipo. Por último, sin ningún ambiente representado encontramos también un alto porcentaje de la muestra, en total el $32 \%$ de portadas analizadas.

Más laborioso ha resultado identificar los objetos y edificios (gráfica 7) que están presentes en las portadas de los Quijotes adaptados para niños. Sin embargo, de acuerdo con el enfoque comunicativo adoptado y los objetivos que han motivado el estudio iconográfico de esta muestra, es muy notorio que el elemento más veces representado en las ilustraciones de las adaptaciones escolares haya sido la armadura de Don Quijote (22\%), seguido de la lanza $(20 \%)$. También aparecen escudos, espadas, libros, molinos, etc.

Igualmente reveladores y demostrativos de la importancia de la tradición iconográfica seguida para la adaptación escolar del Quijote en estos años (1931-1975) han sido los datos del análisis relativo a la presencia de plantas y animales (gráfica 8). En el caso de las plantas casi siempre aparecen como elementos puramente ornamentales, sin cobrar una especial importancia. Sin embargo, en lo referente a los animales encontramos que la presencia de Rocinante, el caballo de Don Quijote, se hace manifiestamente visible en el $38 \%$ de las portadas de estas ediciones, y en una proporción muy similar se encuentra el burro de Sancho (33\%). Ovejas, insectos y otros animales alcanzan un 9\% de presencia; un dato que igualmente no debemos pasar por alto y que apela de alguna manera a las dosis de realismo de las que pretendían gozar muchas de las ilustraciones realizadas, al elaborarse con minuciosidad y con todo lujo de detalles decorativos enriqueciendo los dibujos de las figuras protagonistas. No obstante, no es esto lo más relevante, y una vez más acudimos a reflexionar sobre la función divulgativa que desempeñó el género de la ilustración infantil en el caso concreto de su aplicación a la obra cervantina, al generar un argumento iconográfico insoslayable protagonizado por las figuras del Quijote, Sancho, su burro y Rocinante, que se constituyeron en elementos indisociables de la obra facilitando su identificación por todo el mundo. 


\section{CONCLUSIONES}

Llegados a este punto, podemos concluir que el análisis pormenorizado que se ha realizado de las portadas de las ediciones escolares del Quijote publicadas entre la II República y el Franquismo (1931-1975) pone de manifiesto una serie de convergencias entre ambos períodos antagónicos políticamente, que exceden precisamente de su marco ideológico de referencia.

Así, este estudio arroja luz sobre la despolitización de la ilustración escolar más representativa de la obra cervantina (la de la portada), en tanto no integró visiblemente el fuerte intervencionismo político que sufrió por parte de los distintos gobiernos que tuvo el país. Creemos, que su adaptación fue una constante incesante que respondió a una creciente popularización de lo que se ha denominado iconografía popular quijotesca ${ }^{17}$, que pondría al Quijote en boca de toda la sociedad, de cultos e incultos, eludiendo el adoctrinamiento político e ideológico pretendido, que muy seguramente quedó relegado a la figura instructora de los maestros, y al margen de la labor editorial y comercial de divulgación de la obra. Prueba de ello serían las estrategias de comunicación desplegadas por editoriales, autores e ilustradores, que recibieron la aprobación política de los gobiernos correspondientes en cada momento, y que a su vez salvaron el control ideológico intencionado sobre la nación que se pretendía mediante el continuo intervencionismo político de la obra. Circunstancias que finalmente revirtieron en el tratamiento uniforme y característico en torno a la figura de Don Quijote, equiparable para los dos momentos políticos enfrentados, o al menos con pocas diferencias visibles desde una perspectiva comunicativa y publicitaria.

De hecho, las inferencias realizadas en este estudio por periodos de las circunstancias que definieron el intervencionismo político alrededor de los textos escolares, vienen a confirmar que, ni la Guerra Civil, que devastó fuertemente el sector librero caracterizándose por un periodo casi de plena ausencia editorial, ni el periodo comprendido entre los años 1939 y 1958, siendo el más duro de la dictadura franquista y en el que reinaba la escasez de textos en las escuelas debido a la elevada actividad de las comisiones depuradoras de libros creadas durante la guerra, y en el que se llevó a cabo la publicación de textos de fuerte carga ideológica y adoctrinadora, ejerciendo un excesivo control de todas las obras destinadas al uso escolar incluido El Quijote, ni el último periodo que va de 1965 a 1975 , que presentó novedades con respecto de los anteriores, como fue la formulación de los nuevos cuestionarios para educación primaria, en un primer intento de modernización de la escuela, que culminó con la Ley General de Educación de 1970, altamente relevante en cuanto a la aparición de nuevos libros de lectura adaptados a las edades de

17. Sobre este tema existe un proyecto de investigación en marcha desde el año 2002 en el Centro de Estudios de Castilla-La Mancha denominado «Iconografía popular del Quijote».

http://www.uclm.es/ceclm/CentenarioQuijote/ 
los alumnos y que revocó la obligatoriedad de la lectura del Quijote para la educación primaria, impidieron que su adaptación continuara viva y en sintonía hacia la universalización iconográfica de la obra. Y así, en general, se observa para todos los periodos, que la labor editorial de adaptación de la obra cervantina al entorno escolar fue permanente, siendo el período comprendido entre los años 1939-1958 el que mayor número de ediciones presenta, con un total de 25 adaptaciones.

Por tanto, la introducción de la obra en el espacio escolar no significó la difusión de un icono quijotesco ideologizado acorde a cada gobierno interventor, sino que contribuyó a su mayor universalización trascendiendo las fronteras del ámbito puramente educativo. Y así, conforme se deriva de la aplicación del método de análisis utilizado (Panofsky, 1980) se comprueba una evolución en la imagen del Quijote escolar para el período estudiado, que desde su significado natural, pasando por su significado convencional, hasta su significado intrínseco, comprende una valoración de su iconología que destaca por su gran universalidad, en tanto Don Quijote se alzó en el héroe español de los niños, y también de los adultos, convirtiéndose en un referente de comportamiento, con carácter apolítico y elogiable por sus grandes valores éticos y morales.

\section{BIBLIOGRAFÍA CITADA}

Adam, Jean-Michel y Bonhomme, Marc (2000). La argumentación publicitaria: retórica del elogio y de la persuasión. Madrid: Cátedra.

Alfaro Torres, Paloma y Sánchez García, Sandra (2006). «La lectura obligatoria del Quijote. Análisis de las ediciones escolares», en Don Quijote en el aula: la aventura pedagógica. Cano Vela, Ángel Gregorio y Pastor Comín, Juan José (coord.). Ciudad Real: Ediciones Universidad de Castilla-La Mancha, pp. 17-26.

Alvar, Carlos; Lucía Megías, José Manuel; Partzsch, Henriette; Pérez Sánchez, Alfonso E.; Sánchez Moltó, M. Vicente (2004). La imagen del Quijote en el mundo. Barcelona: Ed. Centro de Estudios Cervantinos, Lunwerg.

Anderson, J. (1987). «Imágenes de la familia en los textos y vida escolares», Revista Peruana de Ciencias Sociales. 1, pp. 115-135.

Arlandis, Sergio (2009). «Tradición y dinámica editorial: hacia una renovadora visión crítica de la obra de Miguel de Cervantes. La labor editorial de la Academia del Hispanismo», Anales Cervantinos. XLI, pp. 317-331.

Atienza Cerezo, Encarna y Van Dijk, Teun (2010). «Identidad social e ideología en libros de texto españoles de Ciencias Sociales», Revista de Educación. 353, pp. 67-106.

Atienza Cerezo, Encarna (1995-1996). «El contexto en el discurso académico: su influencia en la presentación y desarrollo de la información», Revista Pedagógica, 10-11, pp. 123-129.

Atienza Cerezo, Encarna (2007). «Discurso e ideología en los libros de texto de ciencias sociales», Discurso y Sociedad, 1 (4), pp. 543-574.

Bardin, Laurence (1991). El análisis de contenido. Madrid: Ediciones Akal.

Barton, David y Hamilton, Mary (1998). Local Literacies: Reading and Writing in One Community. Londres y Nueva York: Routledge.

Baudrillard, Jean (1978). Cultura y Simulacro. Barcelona: Kairós. 
Boix, Félix (1925). La litografia y sus orígenes en España. Madrid: Imprenta Gráficas Reunidas.

Brown, J. A. C. (2004). Técnicas de persuasión de la propaganda al lavado de cerebro. Madrid: Alianza Editorial.

Burke, Peter (2010). Eyewitnessing. The uses of images as historical evidence, London GBR: Reaktion Books.

Chartier, Roger (2006). «Materialidad del texto, textualidad del libro» [En línea]. Orbis Tertius: Revista de Teoría y Crítica Literaria, 11(12), pp. 1-15. Disponible en: http:// www.memoria.fahce.unlp.edu.ar/art_revistas/pr.201/pr.201.pdf

Colas Bravo, P. y Corts Giner, M. I. (1990). «Las imágenes en los textos escolares de principios de siglo», Revista de Ciencias de la Educación. 141, pp. 41-60.

De Puelles Benítez, Manuel (1998). «La política del libro escolar. Del franquismo a la restauración democrática», en Historia ilustrada del libro escolar. De la Posguerra a la reforma educativa. Escolano Benito, Agustín (dir.) Madrid: Ediciones Pirámide, pp. 49-72.

Días Armas, Jesús (2003). «Estrategias de desbordamiento en la ilustración de libros infantiles» [En línea], Gulbenkian Casa da Leitura, pp. 1-18. Disponible en: http://www. casadaleitura.org/portalbeta/bo/documentos/ot_jesus_diaz_a.pdf

Durán Armengol, Teresa (2005). «Ilustración, Comunicación, Aprendizaje», Revista de Educación. Número extraordinario, pp. 239-253.

Eco, Umberto (1977). Tratado de semiótica general, Barcelona: Lumen.

Eguizábal Maza, Raúl. (2007). Teoría de la publicidad. Madrid: Cátedra.

Escolano Benito, Agustín (1998). Historia ilustrada del libro escolar en España. De la Posguerra a la reforma educativa. Madrid: Editorial Pirámide.

Escolano Benito, Agustín (1997). Historia ilustrada del libro escolar en España. Del Antiguo Régimen a la Segunda República. Madrid: Editorial Pirámide.

Escolano Benito, Agustín (1998). «Texto e iconografía. Viejas y nuevas imágenes», en Historia ilustrada del libro escolar. De la Posguerra a la reforma educativa. Escolano Benito, Agustín (dir.). Madrid, Ediciones Pirámide, pp. 125-148.

Font, Domènech (1981). El poder de la imagen. Barcelona: Salvat.

Frascara, Jorge (2006). El poder de la imagen: reflexiones sobre comunicación visual. Buenos Aires: editorial Infinito. 2da. Edición.

García Crespo, Clementina (1983). Léxico e ideología en los libros de lectura de la Escuela Primaria (1940-1975). ICE: Universidad de Salamanca.

García Padrino, Jaime (2004). Formas y colores: la ilustración infantil en España. Cuenca: Ediciones Universidad Castilla-La Mancha.

García Puchol, Joaquín (1993). Los textos escolares de Historia en la enseñanza española (1808-1900). Análisis de su estructura y contenido. Barcelona: Publicacions Universitat de Barcelona.

Gauthiert, Guy (1986). Veinte Lecciones sobre la imagen y el sentido. Madrid: Cátedra.

Genette, Gérard (1989). Palimpsestos: la literatura en segundo grado. Madrid: Taurus.

Genette, Gérard (2001). Umbrales. México: Siglo XXI.

Giménez-Frontín, José Luis; Andrés, Ramón; Rius, Rosa (2005). Visiones del Quijote: Hogart, Doré, Daumier, Picasso, Dali, Pons, Matta, Saura. Barcelona: Fundación Caixa Catalunya.

Graham, Allen (2000). Intertextualidad. London: Routledge.

Guereña, Jean-Louis (2008). «¿Un icono nacional? La instrumentalización del Quijote en el espacio escolar en el primer tercio del siglo XX», Bulletin Hispanique. 110 (1), pp. $145-190$.

Lucía Megías, José Manuel (2006). «Catálogos de las ediciones del Quijote (notas para un balance de las publicaciones del IV Centenario)», Anales Cervantinos. XXXVIII, pp. 271-277. 
Martín Requero, María Isabel (1996). Iconografía y Educación. La imagen en los textos de la escuela franquista (1939-1975). Valladolid, Universidad de Valladolid (Tesis Doctoral).

Mckenzie, Donald Francis (1986). Bibliography and the sociology of texts. London: The British Library.

Ortiz de Orruño, José María (1998). «Historia y Sistema Educativo: Un debate necesario», Ayer. 30, pp. $15-23$

Panofsky, Erwin (1980). Estudios sobre Iconología. Madrid: Alianza Editorial.

Petrus Rotger, Antonio (1997). «Tecnología del libro escolar tradicional: diseño, iconografía y artes gráficas», en Historia ilustrada del libro escolar. Del Antiguo Régimen a la Segunda República. Escolano Benito, Agustín (dir.). Madrid: Ediciones Pirámide, pp. 101-122.

Porter, M. E. (2002). Estrategia Competitiva. México: Continental.

Puelles Benítez, Manuel (1997). «La política del libro escolar en España (1813-1939)», en Historia ilustrada del libro escolar. Del Antiguo Régimen a la Segunda República. Escolano Benito, Agustín (dir.) Madrid: Ediciones Pirámide, pp. 47-68.

Ramonet, Ignacio (2000). La golosina visual. Madrid: Debate.

Riley, E. C. (1988). «Don Quixote: from Text to Icon», Bulletin of the Cervantes Society of America, 8, special issue, pp. 103-115.

Rodrigo Martín, I. (2012). Arte y comunicación. Propaganda política y transmisión de valores sociales en la obra de Eduardo Vicente. Madrid: Icono14.

Rodríguez García, Sonia Ester (2008). «Connotación y persuasión en la imagen publicitaria», Gazeta Antropológica. 24 (2), artículo 55.

Sánchez-Redondo Morcillo, Carlos (2004). Leer en la escuela durante el franquismo. Cuenca: Ediciones Universidad Castilla-La Mancha.

Scott Kastan, David (2001). Shaskespeare and the Book. Cambridge: Cambridge University Press.

Sebastián Morillas, Ana; Ayestarán Crespo, Raquel; Rangel Pérez, Celia (2012). Planificando estratégica y gestión de la publicidad. Conectando con el consumidor. Madrid: ESIC.

Sotomayor, María Victoria y Navarrete, Ana María (2005). Don Quijote para niños, ayer $y$ hoy. Madrid: Ministerio de Cultura.

Sureda García Ureda, Bernat (1997). «La producción y difusión de manuales escolares», en Historia ilustrada del libro escolar. Del Antiguo Régimen a la Segunda República. Escolano Benito, Agustín (dir.) Madrid: Ediciones Pirámide, pp. 69-100.

Sureda García, Bernat; Vallespir Soler, Jordi; Alles Pons, Elies (1992). La producción de obras escolares en Baleares (1775-1975). Palma de Mallorca: Edicions Documenta Balear.

Tiana Ferrer, Alejandro (1997). «Los libros de lectura extensiva y desarrollo lector como género didáctico. El Quijote en la escuela. Las gramáticas escolares», en Historia ilustrada del libro escolar. Del Antiguo Régimen a la Segunda República. Escolano Benito, Agustín (dir.) Madrid: Ediciones Pirámide, pp. 255-290.

Urbina, Eduardo y Maestro, Jesús G. (eds.) (2005). Don Quixote Ilustrated: Textual Images and Visual Readings. Pontevedra: Mirabel Editorial.

Recibido: 13 de julio de 2016

Aceptado: 24 de agosto de 2016 